\title{
Correction to: Health-related quality of life in nonvalvular atrial fibrillation patients with controlled or uncontrolled anticoagulation status
}

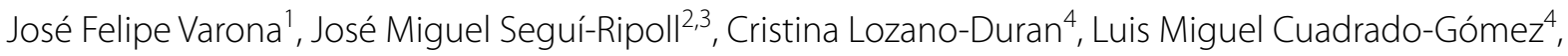
Juan Bautista Montagud-Moncho ${ }^{5}$, Antonio Ramos-Guerrero ${ }^{6}$, José Carlos Mirete-Ferrer ${ }^{7}$, Esther Donado ${ }^{8}$ and Javier García-Alegría $9^{*}$ on behalf of the REQUOL Study Group

\section{Correction to: Health Qual Life Outcomes (2020) 18:383 https://doi.org/10.1186/s12955-020-01563-1}

The original article contains an error in the description of co-author, José Felipe Varona's affiliation.

The correct affiliation can be viewed in this Correction article.

\footnotetext{
Author details

1 Departamento de Medicina Interna, Hospital Universitario HM Montepríncipe, HM Hospitales, Madrid, Spain. ${ }^{2}$ Hospital San Juan de Alicante, San Juan de Alicante, Alicante, Spain. ${ }^{3}$ Department of Clinical Medicine, Miguel Hernández University, Elche, Alicante, Spain. ${ }^{4}$ Hospital Universitario Príncipe de Asturias, Alcalá de Henares, Madrid, Spain. ${ }^{5}$ Hospital Francesc de Borja, Gandía, Valencia, Spain. ${ }^{6}$ Hospital San Juan de Dios del Aljarafe, Bormujos, Seville, Spain. ${ }^{7}$ Hospital de Torrevieja, Torrevieja, Alicante, Spain. ${ }^{8}$ Boehringer-Ingelheim, Sant Cugat del Vallés, Barcelona, Spain. ${ }^{9}$ Hospital Costa del Sol, A-7, Km 187, 29603 Marbella, Malaga, Spain.
}

Published online: 01 April 2021

\section{Reference}

1. Varona JF, et al. Health-related quality of life in nonvalvular atrial fbrillation patients with controlled or uncontrolled anticoagulation status. Health Qual Life Outcomes. 2020;18:383. https://doi.org/10.1186/ s12955-020-01563-1.

\section{Publisher's Note}

Springer Nature remains neutral with regard to jurisdictional claims in published maps and institutional affiliations.

The original article can be found online at https://doi.org/10.1186/s12955020-01563-1.

*Correspondence: jg.alegria@hotmail.com

${ }^{9}$ Hospital Costa del Sol, A-7, Km 187, 29603 Marbella, Malaga, Spain

Full list of author information is available at the end of the article original author(s) and the source, provide a link to the Creative Commons licence, and indicate if changes were made. The images or other third party material in this article are included in the article's Creative Commons licence, unless indicated otherwise in a credit line to the material. If material is not included in the article's Creative Commons licence and your intended use is not permitted by statutory regulation or exceeds the permitted use, you will need to obtain permission directly from the copyright holder. To view a copy of this licence, visit http://creativecommons.org/licenses/by/4.0/. The Creative Commons Public Domain Dedication waiver (http://creativeco mmons.org/publicdomain/zero/1.0/) applies to the data made available in this article, unless otherwise stated in a credit line to the data. 